\title{
The alkaline tide goes out and the nitrogen stays in after feeding in the dogfish shark, Squalus acanthias
}

\author{
Chris M. Wood ${ }^{a, b, *}$, Carol Bucking ${ }^{a, b}$, John Fitzpatrick ${ }^{a, b}$, Sunita Nadella ${ }^{a, b}$ \\ ${ }^{a}$ Department of Biology, McMaster University, 1280 Main St. West, Hamilton, Ontario, Canada L8S 4K1 \\ ${ }^{\mathrm{b}}$ Bamfield Marine Sciences Centre, 100 Pachena Drive, Bamfield, British Columbia, Canada
}

Accepted 13 June 2007

\begin{abstract}
In light of previous work showing a marked metabolic alkalosis ("alkaline tide") in the bloodstream after feeding in the dogfish shark (Squalus acanthias), we evaluated whether there was a corresponding net base excretion to the water at this time. In the $48 \mathrm{~h}$ after a natural voluntary meal (teleost tissue, averaging $5.5 \%$ of body weight), dogfish excreted $10,470 \mu \mathrm{mol} \mathrm{kg}{ }^{-1}$ more base (i.e. $\mathrm{HCO}_{3}{ }^{-}$equivalents) than the fasted control animals (which exhibited a negative base excretion of $-2160 \mu \mathrm{mol} \mathrm{kg}{ }^{-1}$ ). This large activation of branchial base excretion after feeding thereby prevented a potentially fatal alkalinization of the body fluids by the alkaline tide. The rate peaked at $330 \mu \mathrm{mol} \mathrm{kg}^{-1} \mathrm{~h}^{-1}$ at $12.5-24 \mathrm{~h}$ after the meal. Despite a prolonged 1.7-fold elevation in $M_{\mathrm{O}_{2}}$ after feeding ("specific dynamic action"), urea-N excretion decreased by $39 \%$ in the same $48 \mathrm{~h}$ period relative to fasted controls. In contrast, ammonia- $\mathrm{N}$ excretion did not change appreciably. The $\mathrm{N} / \mathrm{O}_{2}$ ratio declined from 0.51 in fasted animals to 0.19 in fed sharks, indicating a stimulation of $\mathrm{N}$-anabolic processes at this time. These results, which differ greatly from those in teleost fish, are interpreted in terms of the fundamentally different ureotelic osmoregulatory strategy of elasmobranchs, and recent discoveries on base excretion and urea-retention mechanisms in elasmobranch gills.
\end{abstract}

(C) 2007 Elsevier B.V. All rights reserved.

Keywords: Feeding; Base excretion; Specific dynamic action; Ammonia; Urea

\section{Introduction}

The term "alkaline tide" was coined by Roberts (1859) to describe the decreased titratable acidity of the urine in humans following a meal, which had earlier been reported by Bence Jones (1845). It was later realized that this reflected a metabolic alkalosis which occurs in the bloodstream after a meal in many vertebrates, and "alkaline tide" came to represent the entire phenomenon (see historical review of Brunton, 1933). The alkalosis is caused by activation of the acid-secreting cells of the stomach as they secrete $\mathrm{HCl}$ into the lumen to facilitate digestion (Niv and Fraser, 2002). Simultaneous and equimolar transport of $\mathrm{HCO}_{3}{ }^{-}$ions (metabolic base) into the extracellular fluid results in alkalinization of the blood. Alkaline tides have been observed in amphibians, reptiles, and mammals (Wang et al., 2001), but until recently had not been seen in fish. Indeed, neither

\footnotetext{
* Corresponding author at: Department of Biology, McMaster University, 1280 Main St. West, Hamilton, Ontario, Canada L8S 4K1. Tel.: +1 905525 9140x23537; fax: +1 9055226066 .

E-mail address: woodcm@mcmaster.ca (C.M. Wood).
}

Taylor and Grosell (2006, in the marine toadfish, Opsanus beta) nor Taylor et al. (2007, in the euryhaline European flounder, Platichthys flesus) could detect a post-prandial alkaline tide in the blood of two teleosts. However, in the marine elasmobranch Squalus acanthias, we have reported that an alkaline tide occurs after both involuntary feeding by stomach tube (Wood et al., 2005), and after natural feeding (Wood et al., 2007). Notably, this opportunistic predator is capable of ingesting very large meals.

In higher vertebrates, the post-prandial alkalosis is partially corrected in the short-term by allowing blood $P_{\mathrm{CO}_{2}}$ levels to rise (i.e. compensatory respiratory acidosis through ventilatory restriction), and in the longer term by secreting $\mathrm{HCO}_{3}{ }^{-}$ from pancreatic, biliary, and duodenal glands into the small intestine, thereby neutralizing the chyme in preparation for its enzymatic digestion (Wang et al., 2001). A small component may also be excreted in the urine (Bence Jones, 1845; Roberts, 1859; Brunton, 1933; Rune, 1966; Vaziri et al., 1980). However, in water-breathers, the gills are generally hyperventilated with respect to $\mathrm{CO}_{2}$ excretion, and this, combined with the presence of extracellular carbonic anhydrase in elasmobranchs, probably makes $\mathrm{CO}_{2}$ retention virtually impossible (Wood et al., 1994b; 
Gilmour et al., 1997, 2001; Henry et al., 1997; Wilson et al., 2000; Gilmour and Perry, 2004). Indeed, in the dogfish, there was no compensating rise in blood $P_{\mathrm{CO}_{2}}$ during the alkaline tide (Wood et al., 2005). Furthermore, it is generally accepted that the kidney plays a negligible role in dynamic acid-base regulation in sharks (Hodler et al., 1955; King and Goldstein, 1983). Therefore, we might expect either a greater secretion of $\mathrm{HCO}_{3}{ }^{-}$ into the intestine or compensation by additional mechanism(s). The present study focuses on the latter possibility.

Wang et al. (2001) speculated that an alkaline tide, if it occurred in fish, might be compensated by base excretion across the gills. Indeed, $S$. acanthias has a remarkable capacity to resist alkalosis during experimental $\mathrm{HCO}_{3}{ }^{-}$loading, accomplished by branchial excretion of base $\left(\mathrm{HCO}_{3}{ }^{-}\right.$equivalents $)$at a high rate (Wood et al., 1995; Tresguerres et al., 2005, 2006). Therefore, our primary goal was to measure whether there was elevated base excretion into the external water across the gills, using a natural "feeding frenzy" protocol in which dogfish were fed a large group meal in their holding arena, and then quickly transferred to individual experimental chambers. Our results are novel in revealing a very large and prolonged excretion of base to the external water after feeding in this marine elasmobranch. This is the first time that the phenomenon has been seen in any waterbreathing animal, and contrasts markedly with a recent report on teleost fish (Taylor et al., 2007). As such, this finding provides a reason why highly efficient mechanisms for excretion of metabolic base are naturally present in the gills of sharks.

Additional goals were to measure post-feeding $\mathrm{O}_{2}$ consumption and nitrogenous waste excretion (ammonia-N and urea-N) in these fish. While the "specific dynamic action" (SDA) effect of feeding on $M_{\mathrm{O}_{2}}$ has been widely studied in teleosts (reviewed by Jobling, 1994), we are aware of only one demonstration of the phenomenon in elasmobranchs (Sims and Davies, 1994). In ammoniotelic teleosts, the SDA is almost always accompanied by greatly increased ammonia-N excretion (e.g. Alsop and Wood, 1997; McKenzie et al., 2007; reviewed by Wood, 2001). However in the ureotelic dogfish, there was negligible rise in either ammonia- $\mathrm{N}$ or urea- $\mathrm{N}$ excretion after feeding; indeed urea-N excretion actually fell non-significantly after the meal in the study of Wood et al. (2005). These observations suggest that the ingested protein was used for anabolic reactions rather than aerobic oxidation (Wood et al., 2005; Kajimura et al., 2006). In the present study, parallel measurements of $\mathrm{O}_{2}$ consumption and nitrogenous waste excretion after feeding provided strong support for this conclusion. This demonstration that the $\mathrm{N} / \mathrm{O}_{2}$ ratio drops markedly after feeding in the shark is novel, because in most aquatic animals, including all teleosts, the opposite occurs. The necessity for urea-N conservation in the elasmobranch provides an explanation for this difference.

\section{Materials and methods}

\subsection{Animal collection, holding, and feeding}

Dogfish sharks (S. acanthias, 1.9-5.7 kg) of both sexes were collected by trawl or by angling in Barkley Sound, British Columbia in June and July 2006. Animals were cared for in accord with the principles of the Canadian Council for Animal Care, and protocols were approved by institutional animal care committees.

The fish were held as a large group ( $\sim 50$ animals $)$ for several weeks prior to experimentation in a 151,0001 circular indoor tank served with running seawater at the experimental temperature $\left(12 \pm 1^{\circ} \mathrm{C}\right)$, salinity $(32 \pm 1 \mathrm{ppt})$, and $\mathrm{pH}(7.90 \pm 0.15) . S$. acanthias will not readily feed when held in small tanks, but in the large group tank, a few fish started feeding after 1 week in captivity, and thereafter, the others quickly learned to do so, as reported by Kajimura et al. (2006). The entire batch were then placed on a feeding regime where they were fed every fifth day with freshly thawed whole hake (Merluccius productus) from which the heads had been removed. This is one of the most common natural preys of dogfish in British Columbia coastal waters (Jones and Geen, 1977). A "feeding frenzy" ensued, and all the food was consumed within $30 \mathrm{~min}$. The ration supplied at each feeding was about $3 \%$ of body mass, based on the estimated mass of all the dogfish in the group tank. However, not all dogfish ate on each occasion, and in a separate trial, the average mass of food consumed by those dogfish which had fed was $5-6 \%$ of body weight, based on autopsy at $24 \mathrm{~h}$ post-feeding. With practice, it was possible to discern which dogfish had fed by the bulging profile of the abdomen, and at $1 \mathrm{~h}$ after feeding, these animals were caught by dip-net and transferred to individual experimental chambers (seawater flow $=11 \mathrm{~min}^{-1}$ ). These consisted of 401 polyurethane-coated wooden boxes fitted with perimeter aeration for thorough mixing as described by Wood et al. $(1995,2005)$. The boxes were bathed in an external running seawater bath to maintain temperature $\left(11-13^{\circ} \mathrm{C}\right)$ when flow-through was suspended for the flux and $\mathrm{O}_{2}$ consumption measurements. Control animals were treated identically, but were removed from the holding tank immediately before feeding, i.e. after 5 days of fasting, a period which is sufficient to virtually clear the gastrointestinal tract (Wood et al., 2007).

\subsection{Measurements of acid-base and $N$-fluxes to the water}

The dogfish were allowed to settle in their individual boxes for an additional hour, so the first flux rate measurements started at approximately $2 \mathrm{~h}$ post-feeding. Fluxes were measured at $2-6 \mathrm{~h}$, $6-12 \mathrm{~h}, 12.5-24 \mathrm{~h}, 24.5-36 \mathrm{~h}$, and $36.5-48 \mathrm{~h}$ after feeding. This $48 \mathrm{~h}$ period was selected to avoid the confounding effects of defecation which occurred at longer times. At the start of a flux period, the water inflow to the box was stopped, and the volume set to a known level (about $35 \mathrm{l}$ after subtraction of dogfish mass). At the end of each 12-h interval, the box was thoroughly flushed with fresh seawater by lowering the water level to the point where the animal's dorsal fin was just exposed, then filling to the top, a procedure which was repeated three times before the volume was reset to 351 . Duplicate water samples were taken at the start and end of a period, and measured for titration alkalinity and total ammonia. Titratable alkalinity was determined by titration of $10 \mathrm{ml}$ water samples to $\mathrm{pH} 4.0$, using a Radiometer-Copenhagen GK2401C combination electrode, and a Gilmont microburette to dispense standardized acid $(0.04 \mathrm{~N} \mathrm{HCl})$. Total ammonia concentration was measured by the indophenol blue method (Ivancic 
and Degobbis, 1984) and total urea by the diacetyl monoxime method (Rahmatullah and Boyde, 1980). Fluxes were calculated from changes in concentration, factored by volume, time, and dogfish mass, and expressed as $\mu \mathrm{mol} \mathrm{kg}^{-1} \mathrm{~h}^{-1}$. In the case of ammonia and urea, the units were $\mu$ mol $\mathrm{N} \mathrm{kg}^{-1} \mathrm{~h}^{-1}$ (i.e. $1 \mathrm{~N}$ per ammonia molecule, $2 \mathrm{~N}$ per urea molecule). Net acid-base flux was measured as the difference between the flux of titratable alkalinity and the flux of total ammonia to the external water (McDonald and Wood, 1981; McDonald et al., 1982). A positive difference represents net base (i.e. $\mathrm{HCO}_{3}{ }^{-}$equivalent) flux, and a negative difference represents net acid (i.e. $\mathrm{H}^{+}$) equivalent flux.

At the end of the 48-h period, the dogfish were lightly anaesthetized with MS-222, weighed, and removed to an operating table. The external surface was inspected for fin abrasion, which can artificially elevate urea-N excretion by blood leakage (Wood et al., 2005), and the gastro-intestinal tract was flushed with seawater to confirm that the animals had indeed fed. Based on these inspections, and the additional criteria that data were rejected from any animals which vomited during the experiment, data were used from 11 fed and 6 control dogfish.

\subsection{Measurements of $\mathrm{O}_{2}$ consumption rate}

A separate experimental series was performed employing a virtually identical protocol on eight fed and four control dogfish. However, in these trials, the box was maintained on open-flow through with continual flushing by fresh seawater $\left(11 \mathrm{~min}^{-1}\right)$, except during $\mathrm{O}_{2}$ consumption measurements. For these, the inflow and aeration were stopped, the volume set to a known level (about 351 again), and a tightly sealing floating lid (styrofoam, coated in plastic) was applied to the water surface. $\mathrm{O}_{2}$ consumption rate, expressed as $\mu \mathrm{mol} \mathrm{kg} \mathrm{kg}^{-1} \mathrm{~h}^{-1}$, was calculated from the decline in water $P_{\mathrm{O}_{2}}$ over a 15-45 min period, depending on animal size and rate of metabolism. Solubility constants from Boutilier et al. (1984) were used to convert $P_{\mathrm{O}_{2}}$ values to $\mathrm{O}_{2}$ concentrations in seawater. $P_{\mathrm{O}_{2}}$ was measured using a Radiometer E5036 electrode kept at the experimental temperature with a water jacket, and displayed on a Radiometer pHM 71 meter. Measurements were made in the intervals $2-3 \mathrm{~h}, 5-6 \mathrm{~h}$, 9-10 h, 13-14 h, 19-20 h, 25-26 h, 31-32 h, 41-42 h, 50-51 h, $65-66 \mathrm{~h}$, and $74-75 \mathrm{~h}$ post-feeding. In preliminary trials with this system, the $P_{\mathrm{O}_{2}}$ levels in the water (in the absence of dogfish) were set to values as low as 30 Torr (far below the lowest levels ever recorded in the experimental tests) and closed for up to $2 \mathrm{~h}$ in order to evaluate whether diffusive leakage of $\mathrm{O}_{2}$ from the atmosphere was a complicating factor. There was never any detectable change ( $<1$ Torr) in water $P_{\mathrm{O}_{2}}$. Other tests were performed to check for "blank $\mathrm{O}_{2}$ consumption", and to ensure that the ventilation of the dogfish provided adequate mixing in the respirometers. There was never any detectable "blank $\mathrm{O}_{2}$ consumption" or regional heterogeneity in water $P_{\mathrm{O}_{2}}$.

\subsection{Statistics}

Data have been reported as means \pm 1 S.E.M. (N). Two-way analysis of variance (repeated measures) was used to detect over- all effects of feeding and time. The least significant difference (LSD) test was applied to detect specific differences within a treatment group (control or fed); means not sharing the same case letters are significantly different. Specific differences between treatments at the same sampling times were evaluated using Student's unpaired two-tailed $t$-test and marked with asterisks. A significance level of 0.05 was used throughout.

\section{Results}

\subsection{Acid-base fluxes}

There were significant overall effects of both feeding and time on net base excretion to the water. At $2-6 \mathrm{~h}$, net base flux to the water was negative and not significantly different in the control and fed treatments (Fig. 1A and B), i.e. both groups exhibited a net acid excretion to the water, perhaps reflecting a disturbance response in this first period after transfer to the boxes. However thereafter, the responses differed. The fed fish exhibited a net base excretion to the water during all periods from

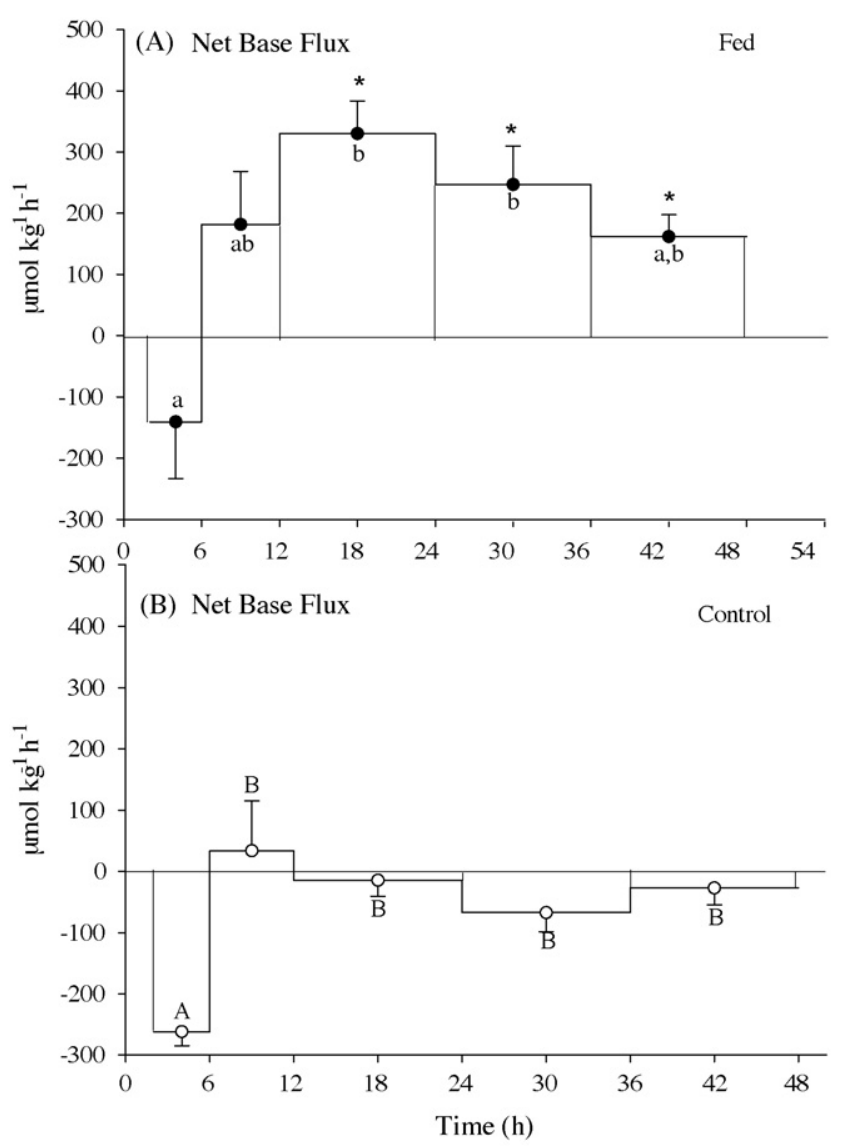

Fig. 1. (A) Net flux rate of base (i.e. $\mathrm{HCO}_{3}{ }^{-}$equivalents) into the external water after feeding in dogfish sharks $(N=11)$. Dogfish were fed at $0 \mathrm{~h}$, transferred to experimental boxes at $1 \mathrm{~h}$, and flux measurements were started at $2 \mathrm{~h}$. (B) Net flux rate of base (i.e. $\mathrm{HCO}_{3}{ }^{-}$equivalents) into the external water in identically handled control animals $(N=6)$ which were fasted for 5 days and not fed before the transfers. Positive flux indicates net base excretion, negative flux indicates net acid excretion. Means \pm 1 S.E.M. Asterisks indicate significant differences $(p<0.05)$ between the fed and control dogfish at the same flux period. Within a treatment, means not sharing the same letter are significantly different $(p<0.05)$. 
$6 \mathrm{~h}$ through $48 \mathrm{~h}$, peaking at $330 \mu \mathrm{mol} \mathrm{kg} \mathrm{k}^{-1} \mathrm{~h}^{-1}$ at $12.5-24 \mathrm{~h}$ after the meal (Fig. 1A), while the fasted controls had a net flux that was not significantly different from 0 at these times (Fig. 1B). Differences between the two treatments were significant at $12.5-24 \mathrm{~h}, 24.5-36 \mathrm{~h}$, and $36.5-48 \mathrm{~h}$. Integrated over the 2-48 $\mathrm{h}$ time period, the fed fish excreted $10,470 \mu \mathrm{mol} \mathrm{kg}^{-1}$ of base (i.e. $\mathrm{HCO}_{3}{ }^{-}$equivalents) relative to the control group.

Differences between treatments were entirely due to differences in titration alkalinity fluxes (Fig. 2A), which exhibited virtually identical patterns of change and significant differences between treatments as those in net base excretion (Fig. 1A and B). There were no significant differences at any time in net ammonia excretion rates between treatments (Fig. 2B).

\section{2. $N$-fluxes}

As expected, ammonia-N excretion rates (Fig. 2B) were much lower than urea-N excretion rates in these ureotelic animals (Fig. 3C), and exhibited no significant overall effect of time or treatment. The only significant effect in ammonia-N flux was a small elevation at $2-6 \mathrm{~h}$ after feeding in the experimental treat-


Fig. 2. Net flux rates of (A) titratable alkalinity, (B) ammonia-N, and (C) urea-N in fed (light bars, $N=11$ ) and control (fasted for 5 days, $N=6$ ) dogfish sharks. Details of treatment as in legend of Fig. 1. Means \pm 1S.E.M. Asterisks indicate significant differences $(p<0.05)$ between the fed and control dogfish at the same flux period. Within a treatment, means not sharing the same letter are significantly different $(p<0.05)$.

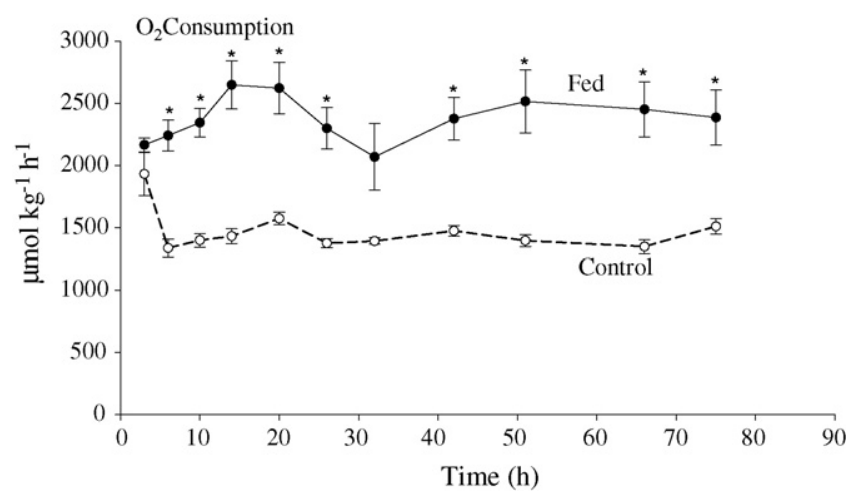

Fig. 3. Oxygen consumption rates of fed (closed circles, $N=8$ ) and control (fasted for 5 days, $N=4$ ) dogfish sharks. Details of treatment as in legend of Fig. 1. Means \pm 1 S.E.M. Asterisks indicate significant differences $(p<0.05)$ between the fed and control dogfish at the same time period. Within the fed treatment, there were no significant differences over time. Within the control treatment, the first value (at $2-3 \mathrm{~h}$ ) was significantly elevated relative to successive values, which did not differ from one another.

ment (Fig. 2B). However, urea-N flux demonstrated a significant influence of treatment alone. Surprisingly, urea-N excretion rates were substantially lower in the fed group, and the individual differences between treatments became significant at $12.5-24 \mathrm{~h}$, $24.5-36 \mathrm{~h}$, and $36.5-48 \mathrm{~h}$ (Fig. 2C). Integrated over the $2-48 \mathrm{~h}$ time period, the fed fish excreted $39 \%$ less urea- $\mathrm{N}$ than the fasted controls, a difference amounting to $11,510 \mu \mathrm{mol}-\mathrm{N} \mathrm{kg}^{-1}$

\section{3. $\mathrm{O}_{2}$ consumption rates}

Except at the first measurement period after transfer to the boxes, $\mathrm{O}_{2}$ consumption rates $\left(M_{\mathrm{O}_{2}}\right)$ were approximately 1.7 -fold higher in the fed dogfish than in the control animals throughout this experiment, which was continued through to $75 \mathrm{~h}$ (Fig. 3). Rates in both groups were more or less constant, so a consistent difference was maintained, significant at all time points except the $2-3 \mathrm{~h}$ and $31-32 \mathrm{~h}$ points. Thus there was a significant overall effect of treatment but not time. Integrated over the $2-48 \mathrm{~h}$ period, the "extra" $\mathrm{O}_{2}$ consumption in the fed animals was about $43,000 \mu \mathrm{mol} \mathrm{kg}^{-1}$, while over $2-75 \mathrm{~h}$ it was approximately $71,000 \mu \mathrm{mol} \mathrm{kg}^{-1}$.

In the fed fish, the nitrogen quotient $(\mathrm{NQ}=[\mathrm{ammonia}-$ $\mathrm{N}+$ urea-N excretion $] / \mathrm{O}_{2}$ consumption) was about 0.19 for most of the experimental period, whereas for the non-fed control animals, the N.Q. was about 0.51 .

\section{Discussion}

\subsection{Post-feeding metabolic rate and N-metabolism}

$M_{\mathrm{O}_{2}}$ increased about 1.7-fold after feeding in S. acanthias, and remained elevated at this stable level through $75 \mathrm{~h}$ postfeeding (Fig. 3). This prolonged SDA is in accord with the very slow digestive processing of the meal in this species, which takes about $120 \mathrm{~h}$ (Wood et al., 2007). To our knowledge, the effects of feeding on metabolic rate have been measured in only one other elasmobranch, the European lesser spotted dogfish 
(Scyliorhinus canicula), where a larger meal (7\% of body weight as squid) caused a 2.8 -fold increase in $M_{\mathrm{O}_{2}}$, peaking at $4-10 \mathrm{~h}$, and returning to control levels by $72 \mathrm{~h}$ (Sims and Davies, 1994). The difference in pattern may be ascribed to a higher temperature $\left(15^{\circ} \mathrm{C}\right)$, more digestible food source, and faster digestion time in $S$. canicula.

Assuming that the average meal was $5.5 \%$ of body weight, with a water content of $80 \%$ (Wood et al., 2007), then each dogfish ate $11 \mathrm{~g} \mathrm{~kg}^{-1}$ of biological material in the present study. Some of this was undoubtedly of little nutritional value (e.g. bone, scales), so a reasonable estimate of the total energy content of the teleost fish meal would be about $20 \mathrm{~kJ} \mathrm{~g}^{-1}$ (Jobling, 1983) or $220 \mathrm{~kJ}$ per meal for a $1 \mathrm{~kg}$ dogfish. Applying an oxycalorific equivalent of $13.55 \mathrm{~kJ} \mathrm{~g}^{-1} \mathrm{O}_{2}$ (Brett and Groves, 1979), then the oxycalorific value of the meal was about 507,000 $\mu \mathrm{mol} \mathrm{O}_{2} \mathrm{~kg}^{-1}$, whereas only $71,000 \mu \mathrm{mol} \mathrm{O} \mathrm{kg}^{-1}(14 \%)$ of its energy content was "wasted" in SDA up to $72 \mathrm{~h}$. Even if this elevated $M_{\mathrm{O}_{2}}$ were to continue for the full 5 days of digestion, this "wastage" would increase to only $23 \%$, which compares favourably with teleost values in the 15-40\% range (Jobling, 1994)

S. acanthias appears to be similarly economical with its $\mathrm{N}$ budget. In two previous studies using smaller meal sizes (Wood et al., $2005-2 \%$ of body weight; Kajimura et al., $2006-3 \%$ of body weight) we have reported that there was no significant change in urea- $\mathrm{N}$ excretion (the major $\mathrm{N}$-waste), but a very slight rise in ammonia- $\mathrm{N}$ excretion (a minor $\mathrm{N}$-waste) after a meal. In one of these, the urea- $\mathrm{N}$ excretion rates were virtually identical in fed and starved animals (Kajimura et al., 2006), but in the other (Wood et al., 2005), urea-N excretion in the first $45 \mathrm{~h}$ after the meal was actually lower by $3200 \mu \mathrm{mol} \mathrm{N} \mathrm{kg}-1$. The present results using a larger meal size $(5.5 \%$ of body weight) confirm this pattern (Fig. 2B and C), and for the first time have revealed a significant post-prandial decrease in urea$\mathrm{N}$ excretion (Fig. 2C). Over $48 \mathrm{~h}$, this $\mathrm{N}$-conservation amounted to $11,510 \mu \mathrm{mol} \mathrm{N} \mathrm{kg}^{-1}$, a substantial saving amounting to $39 \%$ less urea-N excretion. Earlier we speculated that this opportunistic predator was severely $\mathrm{N}$-limited in nature because of its irreducible urea-N loss rate across the gills associated with a ureotelic osmoregulation strategy (Wood, 2001; Wood et al., 2005; Kajimura et al., 2006). The present results re-enforce the idea of post-prandial $\mathrm{N}$-conservation, very different from the pattern seen in teleosts (Wood, 2001), and suggest that it is possible for $S$. acanthias to at least temporarily reduce the rate of urea-N loss across the gills after a meal.

Following feeding, there is an intense activation of urea-N synthesis by the ornithine-urea cycle enzymes in the muscle and liver, and blood urea-N levels rise (Kajimura et al., 2006; Wood et al., 2007). The actual rise in blood urea-N concentration is

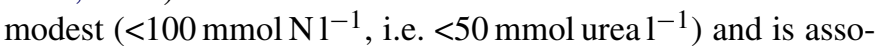
ciated with only a $40 \mathrm{mos} \mathrm{mol} \mathrm{kg}^{-1}$ rise in plasma osmolality. Rather than creating osmotic disturbance, this likely reduces the costs of osmoregulation at this time by obviating the need for the low level seawater drinking which is seen in starved specimens of $S$. acanthias (Webb and Wood, 2000). The fact that blood urea levels do not rise to a greater extent in the face of increased urea production and decreased urea excretion rates is likely explained by the large secretion of urea which occurs into the gastro-intestinal chyme at this time (Wood et al., 2007). This urea secretion is later reabsorbed, but in the interim serves to raise chyme osmolality equal to that of the body fluids - in other words, the internal "urea space" increases at this time (Wood et al., 2007). Larger meals would likely require larger amounts of gastro-intestinal urea secretion, so in future studies, it could be of interest to test whether increased urea-N retention is associated with greater meal size. In natural "feeding frenzy" regimes such as used in the present study, it is not possible to accurately control or measure the ration consumed by individual animals when feeding voluntarily, so this would require a forcefeeding approach, thereby avoiding some of the variability that may confound natural feeding regimes.

The major site of urea-N loss ( $>90 \%)$ is across the gills in this species, not surprising given the massive blood-to-water gradient and high gill surface area (Wood et al., 1995). However, this loss rate is limited by both a $\mathrm{Na}^{+}$-coupled back-transport mechanism and a unique lipid composition which renders the branchial membranes unusually impermeable to urea (Pärt et al., 1998; Fines et al., 2001). The present data raise the prospect that these mechanisms may be modulated in some way after feeding to ensure even greater $\mathrm{N}$-conservation for urea synthesis. By analogy to teleosts, protein synthesis is also likely activated, but this has not yet been measured in elasmobranchs after feeding (Wood, 2001).

Indeed the decline in $\mathrm{N} / \mathrm{O}_{2}$ ratio from about 0.51 in starved animals to 0.19 after feeding provides strong evidence that anabolic processes (e.g. urea synthesis, protein synthesis) were activated after the meal. By way of comparison, a ureotelic teleost, the Lake Magadi tilapia (Alcolapia grahami) exhibited an almost identical $\mathrm{N} / \mathrm{O}_{2}$ ratio of $0.18-0.20$ in fed animals collected fresh from the wild, but this ratio declined as protein oxidation declined during starvation in the laboratory (Wood et al., 1994a). In an ammoniotelic teleost, the rainbow trout (Oncorhynchus mykiss), the $\mathrm{N} / \mathrm{O}_{2}$ ratio was similarly 0.19 in satiation-fed animals, and again declined during starvation (Alsop and Wood, 1997). Given that the theoretical maximum $\mathrm{N} / \mathrm{O}_{2}$ ratio is 0.27 when aerobic metabolism is fueled entirely by protein oxidation (i.e. 100\%; van den Thillart and Kesbeke, 1978), then in both elasmobranchs and teleosts, protein oxidation supports about $70 \%$ of aerobic metabolism in freshly fed animals. However, while this is a time of maximum protein burning and $\mathrm{N}$-excretion in teleosts, it is a time of minimum protein burning and $\mathrm{N}$-excretion in the elasmobranch. In turn, this suggests that amino acids are always the major aerobic fuel source in the dogfish, in accord with the conclusion of Ballantyne (1997) that amino acid oxidation supplies a substantial portion of the energy needs of elasmobranch tissues. Ballantyne (1997) noted in particular the importance of glutamine which serves not only as an oxidative substrate in numerous tissues, but also as the $\mathrm{N}$-donor for urea synthesis.

The situation is very different from that in teleosts, which tend to minimize protein oxidation during fasting (Wood, 2001; McKenzie et al., 2007). Indeed since an $\mathrm{N} / \mathrm{O}_{2}$ ratio of 0.51 in the fasting dogfish is well above the theoretical maximum of 0.27 (van den Thillart and Kesbeke, 1978), this indicates that the starved control animals were not in steady state, i.e. N (mainly 
as urea-N) was being lost faster than $\mathrm{N}$ was being produced by protein breakdown and amino acid oxidation. Similarly, given the switch to N-trapping by protein and urea synthesis after the meal, the fed animals were also probably not in a steady-state condition. Notably, Leech et al. (1979) reported that plasma urea levels and osmolality slowly fell during starvation in S. acanthias. Haywood (1973) demonstrated similar decreases in the pyjama shark (Poroderma africanum) over a 1-month starvation period such that plasma became hypo-osmotic to seawater after 14 days of food deprivation. It is apparent that despite the presence of $\mathrm{N}$-conservation mechanisms, the ureotelic osmoregulatory strategy and protein-based metabolism of elasmobranchs places them at severe risk of $\mathrm{N}$-starvation.

\subsection{Compensation of the alkaline tide}

The present results clearly document that the speculation of Wang et al. (2001) was correct_-in a fish (the marine elasmobranch, S. acanthias) with a marked alkaline tide in the systemic bloodstream (Wood et al., 2005, 2007), the phenomenon is indeed compensated by base excretion across the gills. To our knowledge, this is the first report of compensation of the alkaline tide by base excretion to the external water in any cold-blooded animal, though Busk et al. (2000) observed a small, nonsignificant changeover to net base excretion across the skin at $24-48 \mathrm{~h}$ after massive feeding ( $10 \%$ of body weight meal) in the bullfrog (Rana catesbeiana). It is interesting that in two teleosts there was apparently no alkaline tide after feeding, based on caudal puncture blood measurements (Taylor and Grosell, 2006; Taylor et al., 2007). This conclusion awaits confirmation by cannulation sampling, but it is reinforced by the report of Taylor et al. (2007) that there was no net base excretion to the water in one of the species, the European flounder (Platichthys stellatus). Acid-base flux to the water was not assayed in the other species, the gulf toadfish (Opsanus beta; Taylor and Grosell, 2006).

Why do elasmobranchs and teleosts behave so differently? We speculate that in contrast to elasmobranchs, teleosts exhibit a small or undetectable alkaline tide because the $\mathrm{HCO}_{3}{ }^{-}$generated by $\mathrm{HCl}$ secretion in the stomach is quickly secreted into the intestine, rather than building up in the extracellular fluid or effluxing across the gills to the external environment. It is now clear that intestinal $\mathrm{HCO}_{3}{ }^{-}$secretion is an integral part of osmoregulation in marine teleosts, serving to precipitate divalent cations imbibed by drinking, thereby facilitating intestinal water absorption (reviewed by Grosell, 2006). Furthermore Taylor and Grosell (2006) and Taylor et al. (2007) presented evidence that the process is accelerated after feeding to neutralize the chyme. In contrast, drinking in $S$. acanthias is low to negligible (Webb and Wood, 2000), in accord with the original conclusion of Smith $(1931,1936)$ that ureotelic elasmobranchs do not need to drink seawater. Furthermore, drinking did not appear to be activated after feeding, and intestinal chyme $\mathrm{HCO}_{3}{ }^{-}$concentrations remained low and unchanged during processing of a meal in this species (Wood et al., 2007). In view of the very slow digestion and absorption time in $S$. acanthias revealed in that study, temporal delay between the peak of $\mathrm{HCl}$ secretion in the stomach and the peak of $\mathrm{HCO}_{3}{ }^{-}$secretion in the intestine may play a role in the development of the alkaline tide. However a more important factor may be that much of the $\mathrm{HCl}$ secreted in the stomach will be neutralized in situ by the food, especially by the ingested bone. This was evidenced by the large increase in gastric fluid $\mathrm{pH}$ that was observed after a similar meal in the study of Wood et al. (2007). Thus the amount of $\mathrm{HCO}_{3}{ }^{-}$ needed in the intestine to neutralize the entering chyme is likely only a fraction of the net $\mathrm{HCl}$ secretion in the stomach. In contrast to the teleost, the elasmobranch does not have the option of quickly recycling the excess $\mathrm{HCO}_{3}{ }^{-}$into the intestine, so metabolic alkalosis occurs in the bloodstream, and much of the excess base is excreted across the gills to prevent the blood $\mathrm{pH}$ from rising too high. Nevertheless, the intestinal chyme is precisely neutralized. Wood et al. (2007) have speculated that the $\mathrm{HCO}_{3}{ }^{-}$sources involved may include hepatic bile, the pancreas, or the intestinal cells themselves. This is an important area for future investigation.

Indeed, the need for compensation of post-feeding alkalosis in the absence of an ability to retain $P_{\mathrm{CO}_{2}}$ (see Introduction) may be the reason why dogfish possess such a high capacity to excrete base across the branchial epithelium. Rates as high as $1100 \mu \mathrm{mol} \mathrm{kg} \mathrm{kg}^{-1} \mathrm{~h}^{-1}$ have been reported in dogfish infused with $\mathrm{NaHCO}_{3}$ (Wood et al., 1995). In the present study, the mean base excretion rate peaked at $330 \mu \mathrm{mol} \mathrm{kg}{ }^{-1} \mathrm{~h}^{-1}$ at $12.5-24 \mathrm{~h}$ after the meal (Fig. 1A), and several individual fish achieved rates over $600 \mu \mathrm{mol} \mathrm{kg} \mathrm{k}^{-1} \mathrm{~h}^{-1}$. Interestingly, from the rate of change of blood acid-base status during the first few hours of the alkaline tide, we earlier estimated the rate of metabolic base generation at $450 \mu \mathrm{mol} \mathrm{kg}{ }^{-1} \mathrm{~h}^{-1}$ (Wood et al., 2005), very comparable to the present measurements of the rate of base excretion. Relative to the fasted control animals which exhibited a negative base excretion of $-2160 \mu \mathrm{mol} \mathrm{kg}{ }^{-1}$ over the $48 \mathrm{~h}$ post-prandial period, the fed animals excreted $10,470 \mu \mathrm{mol} \mathrm{kg}{ }^{-1}$ more base. If this massive base excretion had not occurred, at least $10,470 \mu \mathrm{mol} \mathrm{kg}-1$ of base (i.e. $\mathrm{HCO}_{3}{ }^{-}$equivalents) would have to have been buffered in the body fluids by $48 \mathrm{~h}$, and probably more in the longer term.

To put this number in perspective, it is several-fold greater than the estimated $\mathrm{HCO}_{3}{ }^{-}$content of the body fluids (excluding the cartilaginous skeleton) of the whole animal, and is equivalent to the byproduct of $100 \mathrm{ml} \mathrm{kg}^{-1}$ of gastric juice secretion at $\mathrm{pH} 1$ over $48 \mathrm{~h}$ ! It is not possible to precisely calculate the effect on blood $\mathrm{pH}$ without knowledge of how this $10.5 \mathrm{mmol} \mathrm{kg}-1$ $\mathrm{HCO}_{3}{ }^{-}$load might distribute between intra- and extra-cellular compartments. However, applying the traditional technique pioneered by Rune $(1965,1966)$ and now widely used in humans (Niv and Fraser, 2002), the assumption is made that the excess base of the alkaline tide is distributed in a "blood buffer space" equivalent to 0.3 body mass. Using a blood non- $\mathrm{HCO}_{3}{ }^{-}$buffer capacity of nine slykes for $S$. acanthias (Lenfant and Johansen, 1966), the control blood acid-base data of Wood et al. (2005), the Henderson-Hasselbalch equation, the $\mathrm{p} K^{1}$ and $\alpha \mathrm{CO}_{2}$ constants tabulated for elasmobranch blood by Boutilier et al. (1984), and a simple Davenport (1974) diagram analysis, the blood $\mathrm{pH}$ would have risen by about $0.8 \mathrm{pH}$ units in the absence of branchial excretion, in contrast to the $0.25 \mathrm{pH}$ units reported by Wood et al. (2005). This would very likely have been fatal. Indeed the 
fact that dogfish exhibit a rather small Bohr shift in their blood (Lenfant and Johansen, 1966) may be adaptive to sustain $\mathrm{O}_{2}$ unloading to the tissues at a time of some blood alkalosis and heightened metabolic demand after the meal.

The recent immuno-histochemical studies of Tresguerres et al. $(2005,2006,2007)$ have illuminated the mechanism responsible for the efficient excretion of base across the gills in $S$. acanthias during experimental $\mathrm{NaHCO}_{3}$ infusion. In brief, metabolic alkalosis in the blood stimulates a micro-tubule dependent translocation of existing vacuolar proton ATPase (V$\mathrm{H}^{+}$ATPase) molecules from cytoplasmic storage vesicles to the basolateral membrane in a subpopulation of mitochondrial-rich cells in the gills. These cells are also rich in carbonic anhydrase molecules, which appear to play a key role in the process. With prolonged alkalosis, there is later synthesis of additional new V-H ${ }^{+}$ATPase molecules as shown by western blotting. The basolateral V-H $\mathrm{H}^{+}$ATPase activity appears to be fueled by the cytoplasmic carbonic anhydrase, and returns $\mathrm{H}^{+}$ions to the blood. The intracellular $\mathrm{HCO}_{3}{ }^{-}$ions left behind create an electrochemical gradient driving apical $\mathrm{Cl}^{-} / \mathrm{HCO}_{3}{ }^{-}$exchange, such that base is secreted to the environment. It is satisfying to note that this same $\mathrm{V}-\mathrm{H}^{+}$ATPase translocation, together with a twofold increase in $\mathrm{V}-\mathrm{H}^{+}$ATPase abundance by western blotting, were seen in gill samples taken from non-infused dogfish $24 \mathrm{~h}$ after feeding (Tresguerres et al., 2007). This represents the time of maximum base excretion across the gills (Fig. 1A) and a period when plasma $\mathrm{Cl}^{-}$levels actually increase despite elevated gastric $\mathrm{HCl}$ secretion (Wood et al., 2005; Kajimura et al., 2006). $\mathrm{Cl}^{-}$secreted in the stomach is reabsorbed by the lower tract (Wood et al., 2007), so hypochloremia is avoided. In total, these observations suggest that the normal role of this mechanism is to ensure that the alkaline tide goes out after a meal.

\section{Acknowledgements}

We thank the Director and Staff of Bamfield Marine Sciences Centre, especially the Research Co-ordinator Dr. Bruce Cameron, for their assistance and hospitality during the course of this project. Several referees provided very useful comments. Dr. Tobias Wang kindly provided historical references. Funded by an NSERC Discovery Grant to CMW, who is supported by the Canada Research Chair Program.

\section{References}

Alsop, D.H., Wood, C.M., 1997. The interactive effects of feeding and exercise on oxygen consumption, swimming performance and protein usage in juvenile rainbow trout. J. Exp. Biol. 200, 2337-2346.

Ballantyne, J.S., 1997. Jaws: the inside story. The metabolism of elasmobranch fishes. Comp. Biochem. Physiol. B118, 703-742.

Bence Jones, H., 1845. Contributions to the chemistry of the urine. On the variations in the alkaline and earthy phosphates in the healthy state, and on the alkalescence of the urine from fixed alkalies. Phil. Trans. R. Soc. Lond. 135, 335-349.

Boutilier, R.G., Heming, T.A., Iwama, G.K., 1984. Appendix: physicochemical parameters for use in fish respiratory physiology. In: Hoar, W.S., Randall, D.J. (Eds.), Fish Physiology, vol. 10A. Academic Press, Orlando, FL., pp. 403-430.
Brett, J.R., Groves, T.D.D., 1979. Physiological energetics. In: Hoar, W.S., Randall, D.J. (Eds.), Fish Physiology, vol. 8. Academic Press, Orlando, FL, pp. 280-344.

Brunton, C.E., 1933. The acid output of the kidney and the so-called alkaline tide. Physiol. Rev. 13, 372-399.

Busk, M., Jensen, F.B., Wang, T., 2000. Effects of feeding on metabolism, gas transport, and acid-base balance in the bullfrog Rana catesbeiana. Am. J. Physiol., R185-R195.

Davenport, H.W., 1974. The ABC of acid-base chemistry, 6th ed. The University of Chicago Press, Chicago, IL.

Fines, G.A., Ballantyne, J.S., Wright, P.A., 2001. Active urea transport and an unusual basolateral membrane composition in the gills of a marine elasmobranch. Am. J. Physiol. 280, R16-R24.

Gilmour, K.M., Perry, S.F., 2004. Branchial membrane-associated carbonic anhydrase activity maintains $\mathrm{CO}_{2}$ excretion in severely anemic dogfish. Am. J. Physiol. 286, R1138-R1148.

Gilmour, K.M., Henry, R.P., Wood, C.M., Perry, S.F., 1997. Extracellular carbonic anhydrase and an acid-base disequilibrium in the blood of the dogfish Squalus acanthias. J. Exp. Biol. 200, 173-183.

Gilmour, K.M., Perry, S.F., Bernier, N.J., Henry, R.P., Wood, C.M., 2001. Extracellular carbonic anhydrase in dogfish. Squalus acanthias: a role in $\mathrm{CO}_{2}$ excretion. Physiol. Biochem. Zool. 74, 477-492.

Grosell, M., 2006. Intestinal anion exchange in marine fish osmoregulation. J. Exp. Biol. 209, 2813-2827.

Haywood, G.P., 1973. Hypo-osmotic regulation coupled with reduced metabolic urea in the dogfish Poroderma africanum: an analysis of serum osmolality, chloride and urea. Mar. Biol. 23, 121-127.

Henry, R.P., Gilmour, K.M., Wood, C.M., Perry, S.F., 1997. Extracellular carbonic anhydrase activity and carbonic anhydrase inhibitors in the circulatory system of fish. Physiol. Zool. 70, 650-659.

Hodler, J., Heinemann, H.O., Fishman, A.P., Smith, H.W., 1955. Urine pH and carbonic anhydrase activity in the marine dogfish. Am. J. Physiol. 222, $1182-1186$

Ivancic, L., Degobbis, D., 1984. An optimal manual procedure for ammonia analysis in natural water by the indophenol blue method. Water Res. 18, 1143-1147.

Jobling, M., 1983. A short review and critique of methodology used in fish growth and nutrition studies. J. Fish Biol. 23, 685-703.

Jobling, M., 1994. Fish Bioenergetics. Chapman and Hall, London, UK.

Jones, B.C., Geen, G.H., 1977. Food and feeding of spiny dogfish (Squalus acanthias) in British Columbia waters. J. Fish. Res. Bd. Canada 34, 2067-2078.

Kajimura, M., Walsh, P.J., Mommsen, T.P., Wood, C.M., 2006. The dogfish shark (Squalus acanthias) activates both hepatic and extra-hepatic ornithine urea cycle enzyme activities for nitrogen conservation after feeding. Physiol. Biochem. Zool. 79, 602-613.

King, P.A., Goldstein, L., 1983. Renal ammoniagenesis and acid excretion in the dogfish. Squalus acanthias. Am. J. Physiol. 245, R581-R589.

Leech, A.R., Goldstein, L., Cha, C., Goldstein, J.M., 1979. Alanine biosynthesis during starvation in skeletal muscle of the spiny dogfish, Squalus acanthias. J. Exp. Zool. 207, 73-80.

Lenfant, C., Johansen, K., 1966. Respiratory function in the elasmobranch Squalus suckleyi. Respir. Physiol. 1, 13-29.

McDonald, D.G., Wood, C.M., 1981. Branchial and renal acid and ion fluxes in the rainbow trout, Salmo gairdneri, at low environmental pH. J. Exp. Biol. 93, 101-118.

McDonald, D.G., Walker, R.L., Wilkes, P.R.H., Wood, C.M., 1982. H ${ }^{+}$excretion in the marine teleost, Parophrys vetulus. J. Exp. Biol. 98, 403-414.

McKenzie, D.J., Pedersen, P.B., Jokumsen, A., 2007. Aspects of respiratory physiology and energetics in rainbow trout (Oncorhynchus mykiss) families with different size-at-age and condition factor. Aquaculture 263, 280294.

Niv, Y., Fraser, G.M., 2002. The alkaline tide phenomenon. J. Clin. Gastroenterol. 35, 5-8.

Pärt, P., Wright, P.A., Wood, C.M., 1998. Urea and water permeability in dogfish gills (Squalus acanthias). Comp. Biochem. Physiol. A 119, 117-123.

Rahmatullah, M., Boyde, T.R., 1980. Improvements in the determination of urea using diacetyl monoxime: methods with and without deproteinization. Clin. Chem. Acta 107, 3-9. 
Roberts, W., 1859. A contribution to urology, embracing observations on the diurnal variations, in the acidity of the urine, chiefly in relation to food. Lit. Phil. Soc. 15, 238.

Rune, S.J., 1965. The metabolic alkalosis following aspiration of gastric acid secretion. Scand. J. Clin. Lab. Invest. 17, 305-310.

Rune, S.J., 1966. Comparison of the rates of gastric acid secretion in man after ingestion of food and after maximal stimulation with histamine. Gut 7, 344-350.

Sims, D.W., Davies, S.J., 1994. Does specific dynamic action (SDA) regulate return of appetite in the lesser spotted dogfish, Scyliorhinus canicula? J. Fish. Biol. 45, 341-348.

Smith, H.W., 1931. The absorption and secretion of water and salts by the elasmobranch fishes. II. Marine elasmobranchs. Am. J. Physiol. 98, 296-310.

Smith, H.W., 1936. The retention and physiological role of urea in the elasmobranchii. Biol. Rev. 11, 49-82.

Taylor, J.R., Grosell, M., 2006. Feeding and osmoregulation: dual function of the marine teleost intestine. J. Exp. Biol. 209, 2939-2951.

Taylor, J.R., Whittamore, J.M., Wilson, R.W., Grosell, M., 2007. Post-prandial acid-base balance and ion regulation in freshwater and seawater-acclimated European flounder, Platichthys flesus. J. Comp. Physiol. B. 177, 597-608.

Tresguerres, M., Katoh, F., Fenton, H., Jasinska, E., Goss, G.G., 2005. Regulation of branchial $\mathrm{V}-\mathrm{H}^{+}$-ATPase. $\mathrm{Na}^{+} / \mathrm{K}^{+}$-ATPase and NHE2 in response to acid and base infusions in the Pacific spiny dogfish (Squalus acanthias). J. Exp. Biol. 208, 345-354.

Tresguerres, M., Parks, S.K., Katoh, F., Goss, G.G., 2006. Microtubuledependent relocation of branchial $\mathrm{V}-\mathrm{H}^{+}$-ATPase to the basolateral membrane in the Pacific spiny dogfish (Squalus acanthias): a role in base secretion. J. Exp. Biol. 209, 599-609.

Tresguerres, M., Parks, S.K., Wood, C.M., Goss, G.G., 2007. V-H ${ }^{+}$-ATPase translocation during blood alkalosis in dogfish gills: interaction with carbonic anhydrase and involvement in the post-feeding alkaline tide. Am. J. Physiol. R. 292, 2012-2019.

van den Thillart, G., Kesbeke, F., 1978. Anaerobic production of carbon dioxide and ammonia by goldfish Carassius auratus (L.). Comp. Biochem. Physiol. A59, 393-400.
Vaziri, N.D., Byrne, C., Ryan, G., Wilson, A., 1980. Preservation of urinary postprandial alkaline tide despite inhibition of gastric acid secretion. Am. J. Gastroenterol. 74, 328-331.

Wang, T., Busk, M., Overgaard, J., 2001. The respiratory consequences of feeding in amphibians and reptiles. Comp. Biochem. Physiol. A 128, 535 549.

Webb, N., Wood, C.M., 2000. Bioaccumulation and distribution of silver in four marine teleosts and two marine elasmobranchs: influence of exposure duration, concentration, and salinity. Aquat. Toxicol. 49, 111129.

Wilson, J.M., Randall, D.J., Vogl, A.W., Harris, J., Sly, W.S., Iwama, G.K., 2000. Branchial carbonic anhydrase is present in the dogfish, Squalus acanthias. Fish Physiol. Biochem. 22, 329-336.

Wood, C.M., 2001. The influence of feeding, exercise, and temperature on nitrogen metabolism and excretion. In: Anderson, P.A., Wright, P.A. (Eds.), Nitrogen Metabolism, Fish Physiology, vol. 20. Academic Press, Orlando, FL, pp. 201-238.

Wood, C.M., Bergman, H.L., Laurent, P., Maina, J.N., Narahara, A., Walsh, P., 1994a. Urea production, acid-base regulation and their interactions in the Lake Magadi tilapia, a unique teleost adapted to a highly alkaline environment. J. Exp. Biol. 189, 13-36.

Wood, C.M., Perry, S.F., Walsh, P.J., Thomas, S., 1994b. $\mathrm{HCO}_{3}{ }^{-}$dehydration by the blood of an elasmobranch in the absence of a Haldane effect. Respir. Physiol. 98, 319-337.

Wood, C.M., Pärt, P., Wright, P.A., 1995. Ammonia and urea metabolism in relation to gill function and acid-base balance in a marine elasmobranch, the spiny dogfish (Squalus acanthias). J. Exp. Biol. 198, 15451558.

Wood, C.M., Kajimura, M., Mommsen, T.P., Walsh, P.J., 2005. Alkaline tide and nitrogen conservation after feeding in the elasmobranch Squalus acanthius. J. Exp. Biol. 208, 2693-2705.

Wood, C.M., Kajimura, M., Bucking, C.P., Walsh, P.J., 2007. Osmoregulation, ionoregulation, and acid-base regulation by the gastrointestinal tract after feeding in the dogfish shark. J. Exp. Biol. 210, 13351349 . 